\title{
"...Aspects of My Life that I am trying to Understand better": Reinterpreting the Misinterpreted Mother in Doris Lessing's under My Skin and the Grass is Singing
}

\author{
Rabia Ashraf \\ COMSATS Institute of Information Technology, Lahore, Pakistan
}

\section{Introduction:}

An autobiography is as creative as fiction. In fact, any piece of writing is the author's creative production as magnificently portrayed by Ted Hughes in "Thought Fox" via an evocative detail, "Till, with a sudden sharp hot stink of fox/ it enters the dark hole of the head. The window is starless still; the clock ticks / the page is printed." (21-24). Creative process concretizes a part of the abstract historicity of the life of the author and serves as a source of the writer's psychological unveiling. Writing has always been considered akin to a tool for psychotherapy and any piece of literature that contains tinges from the authorial life is purposefully crafted.

With Doris Lessing- a strong British impulse, writing shapes into a process of gaining pleasure and understanding. The Grass is Singing and semi autobiography Under My Skin are readings of psyche and mind; the characters are mentally and psychologically deep, mental illness, feeling of otherness, abandonment and disillusionment operate simultaneously in the undertones of the work and plot. The personal narrative of Lessing in the autobiography is also deeply embedded into psychological probing of the mind. Psychotherapy and more aptly here, literary psychotherapy is a frame within a frame. This frame traverses the distinction that is drawn between the representation of the emotion and the emotion itself.

This research discusses how for Lessing, narrative is a means to an end. The end, as agreed upon is the therapy of the traumatic and negative image building of the mother daughter relation. Feminist and psychoanalytic discourse on mothering and the relationship between mother and daughter reveals how narratives that are daughter centric expose mother as a dynamic and ever present figure in the life of the daughter and even after the mother's death; the memory stays alive as a 
haunting presence (Hallstein 3).Narrative functions at therapeutic end at innumerable instances. Author's life, in consideration here, is the one written down in black and white by the author herself and is assumed to be the lived life and becomes reality and biography at the same time.Though the aspect of matrophobia is evident in Lessing's fiction, it requires textual deconstruction of the works to posit that the author aims to purge this particular matrophobic feeling which is strange and strongly repulsive a daughter experiences in connection to the mother primarily because she realizes that she takes much after her mother as there are quite systematic psychotherapeutic attempts in narrating events and action in the works that are enumerated and discussed with a solid conviction keeping the notion under perpetual consideration that Lessing's writing, particularly the one which is colored with her own life as the subject matter is a means towards therapy where narrative and story line paired with apt;y autobiographical character sketches functionally become a means to this end.

Doris Lessing, British voice of the post war period, delineates the ways through which she attempts to know the unknown and re interpret what is misinterpreted part of her life. In order to decipher meaning out of the chaos of self in the role of a daughter, she makes use of her authorial self.According to Foucault and later, Barthes as stated in "Death of an Author", "The Author is a certain functional principle by which, in our culture, one limits, excludes and chooses...The author is therefore the ideological figure by which one marks the manner in which we fear the proliferation of meaning" ("What is An Author"). Observed from daughter's perspective, the texts portray daughter's lived life as affected by maternal presence or absence. Lessing's writing serves as a source for her to relive that which is lost, also providing her hope that all is yet not lost and she can achieve her purgation of matrophobia through expression and confessions in a therapeutic way. In an attempt to understand her mother by penning her down, Lessing thus is able to understand her sense of 'self'. This psychotherapy contains the central notion of "holding open a space for processes of symbolization into which people come to make new 'sense' of themselves (Bondi 444). Lessing situates her narration in feminism both in her created plots and autobiography. "Narrative is...the most elaborate kind of attempt, on the part of the speaking subject... to situate his or herself..." (qtd. in. Hirsch10). With an attempt towards situating the self, the author allows herself a fresh identity formation.

Unlike male autobiographical writing, women's life writing is largely an exploration of the experiences that are painful other than the overt denial of pain and struggle.The narration is both introspective and reflexive. Lessing's selfwriting thus is emblematic of her past that is repressed and of the reality of her suppressed relations that she stayed in a state of denial of. The two autobiographies 
including Under My Skin (1994) and Walkin the Shade in (1997) describe Lessing's upbringing in Persia and white-ruled Southern Rhodesia, her marriages, divorces and love affairs; her abandonment of her two youngest children; her attraction to and disillusionment with both Communism and sexual romance;her immigration to England, and her life as a writer and single mother.

\section{2: Theoretical Framework}

Any individual's feelings and reactions are based upon past or historic consciousness. Since Greek times, the towering figure of Clytemnestra is unable to forgo and forgive Iphigenia's death (her daughter) so much so that she tilts towards murdering Agamemnon (her husband) in the most ruthless manner that can ever be conceived. Therefore, mother in connection to the son and especially in line with the daughter enjoys a particulary dynamic niche in historical maternal discourses (Ashraf 22).Mother daughter relation bears such a staunch historicity that cannot be undermined or stay unacknowledged. "The womb is the First and the Last place, Earth the greatest mother of them all, from whom we come, to whom we go" (qtd. in. Jennings 14).

Dealing with interpersonal relationships, psychotherapy provides a sense to the chaotic amalgam to the sufferer (Bondi 444). This allows written texts to possess a psychotherapeutic appeal and coloring. Moreover, psychotherapy is highly relational. Liz Bondi sees psychotherapy as a practice that "allows people to communicate emotionally" (443). Similarly 'art therapy' is a method of healing in which through the use of writing, music or paining the creator spills the heart out. In all of modes of representation, one thing remains constant which is the expression and rewriting of the "affective relationships" (Bondi 444). These are those bonds or relationships that play crucial role in one's life. In other words, psychotherapy is the struggle of meaning making that occurs between two people relationally. The ultimate goal is to create new meanings and make older feelings bearable, comprehendible and adjustable.

Regarding self-reflexivity, gauging of relations and their degree of proximity with each other in the process of writing an autobiography, Smith and Watson in their book on genre of women autobiography titled Reading Autobiography, A Guide for Understanding Life Narratives (2010) argue that women autobiography is the traditional or classical mode of self-reflexive writing and they prefer the term "life writing" for it as they argue that it is a general term for writing that takes a life, one's own or another's as a subject (4). Such writing can be biographical, novelistic, historical, or explicitly self-referential and therefore autobiographical 
(4). In the same vein runs Atwood's view in "Paradoxes and Dilemmas, the Woman as Writer" about 'The Quiller- Couch Syndrome'. According to this particular syndrome, masculine style of writing is 'bold, forceful, clear, vigorous etc. while the feminine style includes 'pastel, weak and tremulous expression. In addition Atwood also talks about attaching words like feminine style to be 'confessional, personal or even narcissistic and neurotic (Atwood 75). In this context, Lessing's works are unsentimental yet lyrical and especially, indeed, startlingly alert to the nuances of childhood as she says in her Essay in Time Bites: "In Under My Skin I have a piece about a small girl lying down in the afternoon, and her mother-my mother" ("Writing Autobiography" 100).Use of narratology in psychoanalytic- feminist tradition in woman autobiography reveals that as women take hold of their past and become the authors of their life, the audience or reader understands and shapes the process through fragments of memory. "In psychotherapy...the project of converting private knowledge into narrative form...speakers and listeners mutually influence the story that gets old" (Smith \&Watson 353). This in return amalgamates the experience of self to the entire culture as the macrocosm which is very much relatable to what Adrienne Rich writes in When We Dead Awaken "Revision - the act of looking back, of seeing with fresh eyes, of entering an old text from a critical direction-is for women more than a chapter in cultural history... it is an act of survival (540).

\section{3: Discussion}

From publication perspective, it is noticeable that the time span between The Grass Is Singing (1950) and Under My Skin (1994) is that of more than four decades. There is, therefore, a greater maturity and insightful depth in the autobiography as compared to the novel as Under My Skin is written much time later, becoming an apt textual tool for analyzing the purgatory and cathartic renegotiation of mother's position in the texts.Lessing recreates her past, especially her childhood and reviews her mother from a broader, clearer and more accommodating perspective. Though Lessings' works exhibit a fear, repulsion and threat from the mother figure called matrophobia, a closer textual penetration and analysis of the narrative reveals that self-writing or writing of autobiographical works undoubtedly serve as a source of psychotherapy of this particular phenomenon of matrophobia.

The working of the unconscious violently warps and twists the autobiographical text by adding more and more intricacy to it. The act of self-representational writing involves delving into one's past as an individual's memory constructs it. This applies to whether it is fictional or autobiographical work, distinctions which 
Lessing blurs. Through self-representational writing, Lessing, is able to express the crucial nature of her relationship with her mother. In Memoirs of Survivor, Lessing sheds light upon her personal dreams or memoirs and the most important of those again are the ones associated with her mother about whom she writes that she was one of the most complaining women she ever came across. At repeated intervals, Lessing shows the image of her leaning at her father's wooden leg for childish refuge and shelter due to perpetual detachment offered by her mother. Always concerned about analyzing and understanding her past, she admits in Under My Skin: "For years I lived in a state of accusation against my mother, at first hot, then cold, and hard, and the pain, not to say anguish, was deep and genuine" (UMS 374).Lessing uses her autobiography as a tool to understand her past, and to create a sense of calmness out of the whirlpool of emotions, adolescent tensions and rebellion.

The most central premise of psychotherapy using a literary text, with Lessing is her continued emphasis on relationships, especially the emotional or affective dimensions of all human relations. Relationships and their complexities, is no doubt the subject under consideration for Lessing. She creates a family, though incomplete, unhappy and broken one in The Grass is Singing while in Under My Skin, she has a well setfamily that precludes any fictive changes in the members of the family and the relations that they have with each other. In autobiography, hence, the author is bound and is delimited. She has to play the daughter in its exact essence and she has to present the mother, the way she was. In the fictive work, on the other hand, Mary becomes anybody and everybody that Lessing wants her to be. Mary is based on a woman that Lessing had acquaintance with when she lived in Rhodesia as expressed in one of her interviews (Lessing, "Last Telegraph Interview"). Later, Mary metamorphosizes into more or less the mirror image of Lessing. As Mary's marital relation has its ups and downs, she appears to be based on Lessing's mother so much so that at various moments, Mary's mother seems to be inspired by Lessing's mother, Emily. Such intertwined autobiographical depiction of familial relations asserts that Lessing does not base the protagonist on her own life purposelessly. Mary is shown in relation to her friends and circle before her marriage. Later, she is deeply shown in relation to her husband. The dynamics of her relationship with Dick that remind her of the miserable life of her mother are also confessions based. Even Lessing asserts it quite firmly that she draws the raw material of her stories and the people in the plot from her own life and her heroines are extracted from women who had left some mark in her life. Thus, from daughter's perspective, Lessing analyses her relationship with her mother psychotherapeutically by basing her characters and situations upon real life in order to make amends and reform her old conceptions of her mother and view her life anew. 
Lessing positions her mother in Under My Skin by recalling how she was brought up and reared as a child. This is what Freud's psychoanalytic theory propounds through the concept of Transference. "Everything we do as adults is some how caused by what happened to us a sinfants and trace able to what early care-givers did" (Bondi 440). In Freudian terms, the psychotherapy of any phobia, as matrophobia is under consideration here, is done in two ways. Firstly, either by the process of 'repeating' in which the person unconsciously reenacts the past within an analytic setting and secondly by 'working through' where the person makes the experiences available to his thoughts and relinquishes the symptoms by unconscious reenacting (Bondi 441). The first process of repeating past, glares out in Under My Skin, where life of childhood is as clearly repeated as it can be whereas the second process can be akin to psychotherapy where the experiences (mainly the harsh one as far as her relation with her mother is concerned) are "worked through" as Freud puts it so that the author reaches a point of understanding. Hobson points to the importance of the process of communicating emotional aspects of a particular relationship processes in following words:

Individual's ability to think about, rather than
avoidemotionally important issues is affected by that stance
of some one else.... The ability to think and to speak in
words (a form of symbol) and the ability to communicate
with some one else who registers what you convey, may
keep your heart from breaking or keep your mind from
disintegrating.

(Hobson 24-5)

Under my Skin begins with this sentence in third-person: "She was very pretty but all she cared about was horses and dancing" (UMS 1). Here, Lessing recollects that this was said about her grandmother who died when Lessing's mother was only three years old. A classical autobiography is expected to begin with a sentence about the author. However, the Lessing talks about her grandma, pushes the boundaries of the genre of autobiography in order to capture the complexities of writing a memoir for that matter. Moreover, the fact that she begins her life writing with a sentence about her dead grandmother proves Eakin's point that "all autobiography is relational" (Eakin 43) where the writer relates his persona in relation to the people around him and these are the people who have either helped shape the life of the author or are the ones the author gains inspiration from. This practice is a unique attempt to define one's existence. With Lessing, the text becomes a maternal discourse right at the onset especially when it is established 
that Emily- Lessing's mother could not be a perfect mother as she herself was a deprived child. T

In this connection, it could be stated that the starting part of Under My Skin and The Grass Is Singing can be termed as preliminary quest or understanding of her mother and her relation with her mother. The idea of course comes from the author naming and sharing about the mother or grandmother as soon as the works progress. Even on a surface level reading of these works show that she completely and intensely rejects her relationship with her mother and simultaneously refuses to accept that she is the daughter of her/this mother and is a woman born out of this woman. It becomes important then to deconstruct the story of her birth as shared in Under My Skin, the narrating "I" reconstructs her early childhood and recreates her subjective, customized, modified and fabricated version of her own birth by taking mescaline. In this recreational process, her birth is a beautiful and entirely different experience from the one related to her by her parents. She takes on the role of a story teller who experiments with truth and reality- this is what a semi autobiography allows her to do and describes what soothes and aspires her. "The storyteller invented a birth as the sun rose with light and warmth coming fast into the enormous lamp lit room" (UMS 21). The adult Lessing is traumatized with forceful assimilation that her birth was a painful experience and was a source of an increased sense of disappointment on part of her mother who hoped for a baby boy to cuddle into her arms. "Penis envy" is largely symbolic and should be traced back to its pre-oedipal roots. The penis is a means of sexual access to the mother, which is after all a girl's first loved object. This love inevitably has an erotic component that is especially threatening (to both mother and daughter) in a homophobic society. A woman's desire to have a penis is also bound up with a desire to have a baby with the mother, so that symbiotic unity can be maintained. The wish to have a baby is also a wish to be baby, to redo the early act of being closer to the womb and experiencing the warmth of the mother.This deep rooted foundational imprint of being undesired as a baby girls runs to generations so much so that Lessing, in her real life, is unable to develop the expected relation of love and warmth with her own children. She abandons her own children out of the fear of becoming just like her own mother. She realizes that it is only after leaving her children that she can prevent "eternal chain of repetition... of doom and fatality..." (UMS 262).She states that creating a good birth from the bad one is an attempt of psychotherapy which she is ready to perform manifold times at various stages of her life. Therefore, one cause as to why Lessing wants to be a baby all over again is to re gain the lost attention from the mother. She reenacts a starkly better version of her birth where she is wanted, needed and welcomed into the world with utmost happiness and needed acceptability.It is noticeable that Lessing's knowledge of being an unwanted child as stated directly by the mother, urges her to recreate her 
birth in a better scenario. A woman's role of mothering has gained "psychological and ideological significance" (qtd. in. Shilpa 2) Her defense mechanism against the traumatic experience leads her to create her rebirth imagining "light" and "warmth" that symbolize love and positivity. These, she feels have lacked in her life at its very beginning. Elium \& Elium assert that a girl "seeks equal give and take...their self-esteem is enhanced by knowing that they are part of a relationship..." (2003).

I was giving myself a 'good birth'...the actual birth was not only abad one, but made worse of how it was reported to me...then I invented a chorus of pleasure thatI was a girl for my mother had been sure that I was a boy. Probably this good birth was 'therapeutic.' (UMS 21)

In the same vein of establishing a bond and maintaining self-esteem, Shilpa states that it is during the infancy and early age of the baby girl that her primary bond with the mother is formed. This time period is foundational for the rest of the lives of both the relation holders (Shilpa 4). Lessing's mother could never hide the fact that she disliked her daughter considering her more of a girl than HER daughter. Resultantly Lessing's act of going back to her past and imagining her birth follows Freud's Psychological Defense Mechanism. According to Freud, Defense Mechanism of any individual operates in six different ways namely Repression, Reaction Formation, Regression, Rationalization, Denial and Displacement (Mcleod, par 9). With Lessing, in order to maintain her emotional homeostasis, psychological defense mechanism for her mother's dislike towards her mother is necessary in order to prevent the feelings of anxiety and sorrow. Bowins is of the view that without appropriate and timely initiation of defense mechanism "conscious mind would be much more vulnerable to negatively charged emotional input" (1). Lessing's defensive act is not that of Repression of the very notion of her mother's repulsion towards her. She does not in any way block or evades this memory and the threatening notion of matrophobia from her conscious mind. Contrary, she consciously embraces the truth of being an unwanted and unloved girl or child. Similarly she rejects Denial as a psychological defense mechanism. Her re- creation of past the way she wants it to be asserts that she accepts the way it was in reality. She does not refuse to admit that Harry- her brother's birth was a much celebrated one as compared to hers. Her acceptability of truth- as the world shows her, is not distorted and this is precisely why, in order to deal with it for the rapeutic gains, she modifies reality and uses narration for that.Bowins calls it "Cognitive Distortion" in which the individual tries to white wash reality however is unable to do so (7). Lessing knows and acknowledges the bleak areas to be lightened up through her imagination. As a result, she, through re- living, recreating and re-inventing her past, decides to displace the pent up emotions of 
hostility towards her mother.In order to do so, her reaction formation is akin to Freud's conception of Reaction Formation where the affected individual transforms anxiety, sorrow, danger or threat producing thoughts based on real life experiences into their binary opposites. In this process the ugly images are consciously reshaped into prettier and the dark side is replaced by the brighter. Lessing's use of the words 'warmth' and 'light' for her event of birth vividly portray her Reaction Formation to be a product of her imaginative instinct filled with positivity of which she has the complete control. This defense mechanism makes her the capturer and transformer of history through Rationalization where she justifies being born a baby girl with enhanced plausibility and acceptability and provides better vent to facts.

Freud defines psychoanalysis as "an insight therapy that emphasizes the recovery of unconscious conflicts, motives, and defenses through techniques such as free association and transference" (Weiten 626). In clinical psychotherapy, with Transference, Freud also means the situation "when the patient transfers his earlier... conflicts (those conflicts that led to his symptoms) onto the relationship between the analyst and the patient (the analyzed) ("Psychoanalytic Theory," par 2). The reader assumes that what the text has to offer is truthful and also aims for a transformation or therapy after reading the autobiography. Assuming Lessing as a sufferer here, the reader takes on the role of the analyst. The reader is the one on whose shoulders rest the ability to analyze the dynamics of mother daughter relation is objective way. The re-enactment of past conflicts is done through writing where the repressed and hidden feelings come to light. A successful autobiography becomes the one that... display a person changing and being changed by life's experiences, and sometimes even by the very process of writing the autobiography" (qtd. in. Karen, par1). This is precisely where Jungian and Freudian emphasis on re evoking the memories and feelings of past by re expressing then in order to understand them all over again, gains a common standing.

Lessing's mother in Under My Skin hardly triggers the attention of the reader as a round character. According to reader response theory, a text is what the reader gets or understands out of it. "Reader-response criticism explores how individuals see the same text differently, emphasizing on how religious, cultural, and social values affect the way we responds to text" (Newton 219). The reader would possibly view Mary's or Martha's mothers in different contexts but interestingly, the mothers with Lessing are roughly viewed through daughter's lens or perspective. The daughters are the subject of Lessing's works who objectify the mothers as the story is essentially daughter centric. According to Anca Georgescu, scripting and plot of Lessing's novels and autobiographies function as a medium through which Lessing 
immortalizes the memory of her mother and strives for new selfhood for the mother and daughter (5). Lessing viewed her mother to be more organized, task oriented and efficientand felt often times as to why didn't she run the farm life and do all the earning instead of her father who was weak enough more mentally and physically. Emily (her mother) was a working woman before getting married but she never planned to or thought about working after her marriage for husband's support (UMS 178). In Under My Skin, Lessing writes about her mother, "All her life she knew she had a bad heart and might die at any moment. In the end she died at the respectable age of seventy-three, of a stroke" (UMS 64).

Conflict, is a central thematic premise in Lessing's fiction. This is akin to Jung's concept of conflict according to which, conflict is not only inherent in human psychology, but is necessary for growth. In order to become more conscious, one must be able to bear conflict. The continuous friction between opposites has omnipresence in an individual's life. In addition, there are many internal opposites, as well as those experienced in the outside world other than the personal life like Lessing's shift from one school of thought to another in her practical life. It is this tension between the opposites which if borne, then out of the clash something new and creative has the tendency to emerge. In Jung's view, this 'something' is a symbol that contributes to a new direction which does justice to both sides of a conflict and which is a product of the unconscious rather than of rational thought. Similarly, conflict is the harbinger of individuation. According to Jung, the symbol is something which cannot be fully explained or understood however,it possesses the attributes of both conscious and unconscious worlds (Samuels 75). The symbol may be the agent of transformation which brings about the development which was so important an aspect of thinking, and which leads towards individuation as the goal towards which humans strive. In fact, all dialogue is contained within this Agon- in Greek terminology, Agon is the tension or strain between two women fulfilling two different familial roles and are closely connected to each other.

An in-depth reading of Under My Skin justifies it as a piece of apologia- self justification rather than simple and plain self-documentation. It is an oration of literary kind that is embedded in psychotherapy and is so private in its subject and content that cannot be read aloud in public which is of course the beauty of any autobiography that is badly true. Autobiography delineates author's ability to recall history where the author becomes a recorder, chronicler and historiographer of his life.Lessing juxtaposes fact with fiction in order to create a meaningful sense of the therapy of her 'self' through Historiographic Metafiction which as Hutcheon puts it, is the meaning and the various versions of reality that the writer constructs of life and history (40). Lessing, however re constructs a mother's ever failing role. She is equally fair and explicit in stating that she hates her mother when she 
remembers her deprivations as a child. Her reaction of screaming and screaming all day, as she was fed with cow's milk, declares how unhappy child she has been and her mother kept on relating this incident to her very 'cheerfully' all her life (UMS 23) which Lessing is unable to like. Her history of life, thus takes on the shape of an apology.Later in her life as an old woman only, is Lessing able to join various threads together and term her autobiography as a confession or apologia for she never understood or made an attempt to understand her mother other than being an oppressor, failed wife and mother and a sorrowful woman all her life.

What Lessing wants to achieve is to 'recapture her mother'. She finds herself in a situation of "dereliction" which according to Giorgio is a "state of loss, abandonment, helplessness and ultimately homelessness- in being unable either to access the symbolic or to return to the original home of the mother's body" (12). It is in chapter eight of the autobiography when Lessing's mother comes to know about the Holy Water and rosary with her teenage daughter and decides to scold her for it that Lessing explicitly declares that it was the beginning of the rejection ofher mother (UMS 124). She also adds her mother saying about her in the form of a monologue "You are just like me" to which Lessing states in reply "Her so frequent you are just like me made me white hot with rage" (UMS 150). Regarding her mother's way of reporting a family news to her to the Convent, Lessing states that she had ceased to respond to her "theatrical announcements" and that she could not stand them at all (UMS 151). The letters which Lessing's mother used to write to her when her father was suffering from diabetes also add up to matrophobic connotations. She says "I could not read those letters... who was writing them? I did not recognize the writer" (UMS 152). Her mother only had accusations for her that her studies and piano lessons were making the family bankrupt.

Doris Lessing writes with women centered plots and feminine narrative modes. Through her fictive self, Anna in The Golden Notebook, Lessing is confirming to Woolf's belief that women mostly think back through their mothers. Even Mary in The Grass is Singing continues recalling her mother's plights of life while she resides at the village kopje. But the 'truth' for Lessing, as for everyone, keeps on changing, so that her novels and depictions of past events forever evolve as she attempts to catch hold of this elusive and non-existent truth. Lessing writes multi personal and dialogical 'self-representational' or 'autobiographical' narrators so that they may avoid the presentation of a single or unified truth, which they believe, would be subjective, nostalgic, and distorted due to memory. As Lessing continues to write, the past and therefore the present which rests on that past, is pluralized and enriched. Finally, for each woman like Mary or Martha, it becomes her personal truth and story. 


\section{4: Conclusion}

"Our own views of life change all the time, different at different ages. If I had written an account of myself aged 20 30 -confident and optimistic, at 40-full of guilt and selfjustification.At 50-confused, self-doubting. But at $60 \ldots$ you begin to see yourself from a great distance...You float away from the personal ...detachment, impersonality."

("Writing Autobiography" 92).

In conclusion this assertion is reiterated that the semi-autobiographical text, Under My Skin and the semi fictive text The Grass Is Singing due to embedded subjectivity, role of memory and tinges of authorial real life in them provide a feminist and psychoanalytic understanding. Most importantly the mother figure emerges out to be conflicting and demanding psychotherapy. Re-entering past and seeing it with a sight anewthat is more experienced and mature enough label the process of understanding of Matrophobia to be a successful psychotherapeutic attempt. Lessing's re-creation of her birth, mandatory presence of mother figure in her texts, use of madness, unconscious and dreams to evoke the sad repressed memories make the texts a discourse dealing with the thematic concerns of mothering and motherhood in feminist terms. Lessing is not only emotional about the mother but touches keenly upon the sensitive issue of the deprived female child who hates the mother and fears to repeat living a life like that of the mother. She is also logical and pragmatic when she writes the autobiography as she feels that the dawn of experience allows her to see the predicament of her mother in a far better way. Thus, both Under My Skin and The Grass Is Singingare books that are apt to explore varied feminist dimensions of the psychotherapy of Matrophoia. These interesting texts deal brilliantly with how protagonists are on a passionate quest to reach back the mother's self and identity and to untangle the tangles in the mother daughter relation.

Doris Lessing is visionary and unique fiction writer in terms of narrative and exposure of reality and this is precisely why the writings are sordid, pithy, blunt and open as far as her attempt to write biographical work is concerned. Roberta Rubenstein summarizes in her concluding remarks about Lessing's work that Lessing can be justifiably called one of the unique, major and visionary artists of the contemporary times as she has made an attempt to break through the intellectual preconditions and assumptions of conventional nature in dealing with the issues of life (256). In the similar vein, Lessing is compared to contemporary female writers like the Afro American Maya Angelou and the Canadian Jamaica 
Kincaid as she writes not merely for the sake of writing and satisfying her creative impulse but for fathoming out various unintelligible knots and strands of her life problems through her narrative. Her works, thus serve the purpose of recognizing and understanding her identity especially in relation to her mother who at times appears to be her care giver and guardian and at others an oppressor generating an identity construction issues for the growing up daughter.

\section{References and notes:}

Allardice, Lisa. "Lisa Allardice on Doris Lessing: She Helped Change the Way Womanare Perceived and Perceive Themselves."The Guardian. 13 Nov 2013. Web. 21Dec. 2013.

Ashraf, Rabia. "Psychodynamics of Psychodynamics of Mother Daughter Relationship:Degrees of Deprivation, Oppression and Dispossession in Doris Lessing's Fiction”. Khazar Journal of Humanities and Social Sciences. 20:1. 2017. Print.

Atwood, Margaret. "Paradoxes and Dilemmas, the Woman as Writer, Woman in the Canadian Mosaic.” Feminist Literary Theory- A Reader. Ed. Mary Eagleton.Great Britian: Billing and Sons Ltd. 1990. Print.

Bondi, Liz. "Making Connections and Thinking through Emotions: Between Geography\& Psychotherapy." Transactions of the Institute of British Geographers30.4(2005):433448. Web. 6. Jan 2013.

Bowins, Brad. "Psychological Defense Mechanism: A New Perspective." TheAmerican Journal of Psychoanalysis 64.1(2004): 1-26. Web. 12 Oct 2013.

Boyd, Carol. J. "Mother and Daughters: A Discussion of Theory and Research."Journal Of Marriage and Family. 51. 2 (1989): 291-301. Web. 5 Nov.2013.

Can Emir, Badegül. Literature and Psychology in the Context of the Interaction of Social

Sciences. Khazar Journal of Humanities and Social Sciences. Volume 19,

Number 4. Khazar University Press, Azerbaijan.2016.49-55

Chodorow, Nancy. The Reproduction of Mothering: Psychoanalysis and The Sociologyof Gender. USA: U of California. 1978. Print.

---, "Family Structure and Feminine Personality. "Women, Culture and Society. Ed.Michelle Zimbalist Rosaldo and Louise Lamphere. Stanford: Stanford UP,1974. 43-66. Print.

Flax, Jane. "Mother-Daughter Relationships: Psychodynamics, Politics, andPhilosophy." The Scholar \& Feminist XXX: Past Controversies, PresentChallenges, Future Feminists.3.3. Web . 13. Nov 2013.

---, "The Conflict between Nurturance and Autonomy in Mother-Daughter Relationshipand Within Feminism." Feminist Studies: Towards a Feminist Theory ofMotherhood. 4.2(1978): 171-189. Web. 13. March 2014.

Gardiner, Judith Kegan. "A Wake for Mother: The Maternal Deathbed in Women'sFiction.”Feminist Studies. 4. 2 (June 1978): 146-165. Web. 13 Feb. 2013.

Georgio, Adalgia. Writing Mothers and Daughters: Renegotiating the Mother inWestern Europe. United States: Berghahn Books. 2002. Print. 
Gerorgescu, Anca. "Reconstructing Mother- Daughter Subjectivities through Writingin Doris Lessing's Under My Skin.” Valahia: U of Targoviste P, 1998. Print.

Hallstein, Lynn O'Brien. White Feminists and Contemporary Maternity: PurgingMatrophobia. New York: Palgrave Macmillan, 2010. Print.

Hammer, Signe. Daughters and Mothers: Mothers and Daughters. New York: NewAmerican Library, 1975. Print

Hirsch, Marianne and Evelyn Fox Keller. "Introduction: January 04, 1990." Conflicts inFeminism. Eds. Marianne Hirsch and Evelyn Fox Keller. New York:Routledge,1990. 12.Print.

---, The Mother/ Daughter Plot: Narrative, Psychoanalysis, Feminism. Bloomington andIndianpolis:UP of Indiana. 16. 1989. Print.

---, "Mothering and Mother-Daughter Relationships: Selected Bibliography." Women's Studies Quarterly/Teaching about Women. 11.4 (1983): 38-43. Web. 3 Dec.2013.

Hutcheon, Linda, A Poetics of Postmodernism History, Theory Fiction. New York,London: Routledge: 1988.40. Print.

Karen Hamilton. "Truth in Autobiography." Tripod.com. N.p., n.d. Web. 06 Jan. 2014.

Kincaid, Jamaica. The Autobiography of My Mother. New York: Plume Books, 1996.Print.

Lessing, Doris."Doris Lessing: her Last Telegraph Interview." The Telegraph, TelegraphMedia Group 17 Nov, 2013.

---, "Writing Autobiography." Time Bites- Views \& Reviews. Great Britain: HarperPerennial, 2006. Print.

Rich, Adrienne. Of Woman Born: Motherhood as Experience and Institution. 2nd ed.New York: W.W. Norton, 1986. Print.

Schlueter, Paul. "Self Analytic Woman: The Golden Notebook." "Doris Lessing". 1986.Modern Critical Views. Ed.Harold Bloom. New York: Chelsea HousePublishers. 46-47. Print.

Scott, Lynda. "Writing the Self- Selected Works of Doris Lessing." Deep South. N.d.Web.21 Oct. 2013. Print.

Shilpa, P. "Mother Daughter Relationship: Daughter's Experience." Diss. Bangalore Uof Christ, 2010. Print.

Smith, Sidonie\& Julia Watson. Women, Autobiography, Theory: A Reader. New York:UP of Wisconsin. 1998. Print.

Sukenick, Lynn. "Feeling and Reason in Doris Lessing's Fiction.”1986. ModernCritical Views. Ed.Harold Bloom. New York: Chelsea House Publishers.Print.

"Walking in the Shade: Volume Two Of My Autobiography." Browse Inside Walking inthe Shade: Volume Two of My Autobiography--1949-1962 by Doris Lessing.N.p., n.d. Web. 21 Dec. 2013.

Woolf, Virginia. "A Room of One's Own”. Abrams, M.H. The Norton Anthology ofEnglish Literature. New York: Norton \& Company, 2000. Print. 


\title{
Summary
}

\section{"...Aspects of My Life that I am trying to Understand Better": Reinterpreting the Misinterpreted Mother in Doris Lessing's under My Skin and the Grass is Singing}

\author{
Rabia Ashraf \\ COMSATS Institute of Information Technology, Lahore, Pakistan
}

With the application of psychoanalytic and feminist tradition, the psychotherapeutic aspect of interpreting the mother, concept of motherhood and the phenomenon of mothering using feminist tradition is analyzed in this paper. Doris Lessing, through her self-representational writing, fictive protagonists (based on herself and her mother) and by declaring in the later part of her life that her mother was a personality that demanded more thinking, understanding and empathy on her part instead of repulsion, hatred and fear to be like her which is called matrophobia, it can be stated that this psychotherapy of matrophobia (Ashraf 77) is Lessing's predominant concern in both her novels and autobiographies. However, there are means through which the works emerges out to be psychotherapeutic and tracing out those modes and exploration of the therapy of matrophobia is the primary concern of this research paper.

Keywords: Psycho analysis, feminism, psychotherapy, matrophobia, 